\title{
Impact of applying social responsibility accounting on companies' financial performance
}

\author{
Ayat Karaja ${ }^{1}$ Emad Al Shikh² Israa Mansour ${ }^{3 *}$ \\ 1. Department of Accounting, Processing and Investment of Medical Facilities, Jordan \\ 2. Faculty of Business \& Finance, The World Islamic Science \& Education University, Jordan. \\ 3. Faculty of Business, Applied Science Privet University, Jordan. P.O.Box 166 Amman - Jordan
}

\begin{abstract}
This research aims to examine the impact of applying social responsibility accounting measured through (environment protection, community service, and human resources) on the financial performance of companies measured by Earning per Shear (EPS) and Return on Assets (ROA).

The study population consisted of service companies listed in Amman stock Exchange. To realize the research objectives, analytical descriptive approach was adopted. For testing hypotheses, Multiple Regression Analysis was used. Results showed that there is an application of social responsibility accounting of the selected activities by the Jordanian companies listed in listed in Amman stock Exchange. In addition, there was a statistically significant impact at the level of $(\alpha \leq 0.05)$ for social responsibility accounting whether combined and separately on the financial performance being measured by the EPS and the return on assets in the service companies listed on the Amman Stock Exchange.

Among the recommendations was to increase the awareness of the companies 'administrations about the effects and implications of social activities due to their impact on their financial performance. Officials of the Amman Stock Exchange and other concerned parties have been urged to promote the supervision on companies' commitment to disclose their social activities and to encourage companies to follow the same approach.
\end{abstract}

Keywords: Social Responsibility Accounting, Financial Performance, Services Companies, Earning per Shear, return on Assets.

DOI: $10.7176 / \mathrm{EJBM} / 11-15-17$

Publication date:May $31^{\text {st }} 2019$

\section{Introduction}

Social responsibility accountability has emerged after realizing the need for companies to focus on the objectives of social responsibility in society as well as focusing on the principle of maximizing profits and the value of the company. Social responsibility accounting has undergone a series of successive developments to reach its current state.

In response to the demands of society at the present time along with promoting the interests of companies with all their activities via improving their social responsibility roles - if companies apply social responsibility accounting for realizing their objectives - and in response to such expectations, this research aims to identify the impact of social responsibility not only on society but also to find out if it has retroactive and significant impact on the company's financial performance, its business outcomes and value of its market shares.

\section{Significance of the Research}

The significance of this research stems from its endeavor to identify the reality of applying social responsibility accounting and offer a clear vision on the impact of each of its activities on the financial performance of the service companies listed in the Amman Stock Exchange. This is in addition to enable the administrations to develop appropriate strategies for social responsibility to be suitable in evaluating the financial performance of service companies which constitute one of the economic sectors in Jordan.

\section{Research Problem}

The research problem is summarized in the following questions:

1. What is the extent of applying social responsibility accounting with respect to (environmental protection, community service activities and human resources development activities) in Jordanian service companies?

2. What is the impact of the social responsibility accounting activities on the financial performance as measured by the EPS in service companies listed in the Amman Stock Exchange?

3. What is the impact of social responsibility accounting activities on financial performance measured by return on assets in service companies listed in the Amman Stock Exchange? 


\section{Research objectives}

The objective of the research is to examine the impact of the application of social responsibility accounting on financial performance by identifying whether there is an application of the social responsibility accounting activities in the Jordanian service companies. Also, it aims to find out if these activities have an impact on financial performance measured by EPS and then return on assets in service companies listed in the Amman Stock Exchange.

\section{Research hypotheses}

The research was based on the following hypotheses:

Hol: Jordanian service companies do not apply social responsibility accounting activities in relation to (environmental protection activities, community service activities, and human resources development activities). Ho2: There is no statistically significant impact at $(\boldsymbol{\alpha} \leq \mathbf{0 . 0 5})$ of the social responsibility accounting activities on the financial performance measured by the Earning per Shear in the service companies listed in the Amman Stock Exchange.

Ho3: There is no statistically significant impact at $(\boldsymbol{\alpha} \leq \mathbf{0 . 0 5})$ of the activities of social responsibility accounting on financial performance measured by Return on Assets in service companies listed in the Amman Stock Exchange.

\section{Theoretical framework and past literature:}

Since the early 1960s and 1970s of the 2oth century, companies have realized the importance of social resources. Accordingly, they have started to focus their attention on the growth of projects, providing services and goods to consumers and ensuring the payment of the best wages to their employees through their sole endeavor and its top priority without giving any heed to any other activity towards the society (Al-Asraj, 2011, p.3). Social responsibility has emerged under several names, including organizational commitments, organizational citizenship, organizational ethics, and social accountability. Multiplicity and variation of names went on until "social responsibility accounting" concept emerged independently as a result of the evolution of the concept of corporate social responsibility (Al-Horay et al, 2014). Accounting has managed to realize a new dimension by achieving a set of objectives, namely the social dimension. This is due to the broad circle of interests to include society, environment, government and employees, and the size of companies and the size of their impact. All these impacts and successive developments greatly contributed to the emergence of the term "social responsibility accounting" that didn't exist in the twentieth century, particularly in the last eight decades (Gholami et al., 2012).

\subsection{The concept of social responsibility}

DiSegni et al., 2015 define social responsibility as "a set of activities that measure and analyze the social performance of business organizations and communicate that information to interested groups and parties in order to help them make decisions and assess the social performance of these organizations." Ferell and Fraedrich (13: 2012) consider it as "a commitment of the institution to work on maximizing the positive impact and reducing the negative impact on the community. The American judiciary itself has taken part in the launching of significant provisions with the aim of emphasizing the importance of economic units fulfilling the required social responsibility. This interest has led the owners of professional organizations, scientific research circles and university researchers to take a greater interest in the concept of social responsibility accounting (Kabir \& Thai, 2017).

The corporate social responsibilities are classified into two categories (human and ethical) towards the local community, employees, customers, suppliers, the environment, and shareholders. Social responsibility comes out of the circle of fulfillment of economic and legal obligations as it expands to be a responsibility of moral obligation that has the following dimensions:

a. Social responsibility towards the community:

Organizations seek to strengthen and promote the bonds among each other. This requires further activities by undertaking a range of activities that seek public benefit in general, such as providing university students with training, supporting civil society organizations, honoring customs and traditions, and helping people with special needs out via providing them with financial support, establishing parks, reducing unemployment rates and participating in health care services (Wang et al., 2015).

b. Social responsibility towards employees:

This area is confined to examining the impact of the activities of the organization on the employees, who represent the human resources that work in diligently to fulfill the objectives of the organization, such as the provision of industrial safety and free health insurance. Organizations seek to offer them the optima support for enhancing the human factor. The objective of these activities is to promote an atmosphere of belonging, love, and understanding, and deepen loyalty to the organization by the employees (Chtourou et al., 2017).

\section{c. Social responsibility towards customers and consumer protection}


This category of activities includes everything that seeks to achieve consumer satisfaction and continuity of their satisfaction, such as providing data related to the product such as its expiry date, way of use, serious effect, limitations for use, honest advertising without deceiving the consumer and increasing the product safety. Among the most prominent social roles provided to this category, include honesty regarding the advertisement and the provision of products of reasonable types and prices. This also includes the commitment of organizations to work on addressing the damage resulting from the sale process with ongoing keenness on continuous development of products (DiSegni et al., 2015).

\section{d. Social responsibility towards suppliers}

The relationship between business organizations and suppliers is described as a mutually beneficial relationship. Suppliers hope that business organizations will respect their legitimate demands and hopes, represented in their constant desire to supply resources for productive operations at affordable prices (Magnanelli \& Izzo, 2017)

e. Social responsibility towards the environment

These activities contribute to mitigating the negative impact of the organization's activities and thus influence the environment. These measures seek to preserve the natural resources and preserve the environment. The organization actively seeks to remove the damage from the surrounding environment that is created by the industrial activities, including costs of social performance, costs of protecting water pollution, and natural grass, plantations, marine environment and air pollution (Turcsanyi \& Sisaye, 2013).

\subsection{Objectives of social responsibility accounting}

There are multiple objectives of social responsibility accounting (Famiyeh, 2017):

1. Measuring and determining the net social contribution of the organization, which contains elements of internal and private benefits, cost elements of the organization and social (external) benefits that affect the classes of society.

2. Assessing the social performance of the organization by determining the validity of the objectives of the organization's strategy and ambitions for individuals to achieve an acceptable percentage of profits and social priorities, on the other hand.

3. Highlighting the activities that have social implications by the organization. This objective is related to the accounting communication function. This objective show cases the importance of providing access to appropriate data on the social performance of the organization and its capability to realize social objectives and the delivery of information to the stakeholders.

\subsection{Social Responsibility Accounting (SRA) and Financial Performance}

Financial performance is defined as "a set of consecutive activities that are related to a part-time activity or a specialized function adopted by management to achieve a specific objective" (Gitman et al., 2015).Bhunia and Roy (2011) define financial performance as "an appraisal of the feasibility, solidity and fertility of a business, as reflected in the financial and accounting data that define the financial characteristics and operational process which distinguish an institution from another. Financial performance is one of the key issues in evaluating corporate performance in general. The significance of financial performance stems from its vagueness as the concept of financial performance and its determinants are manipulated by all parties for their own interests. Society, for instance, seeks after the welfare of its individuals and ensuring social justice and economic prosperity. The government seeks to raise tax revenues, while companies aspire for more survival and sustainability, and the shareholder aspires to increase and maximize their wealth (Akisik \& Gal, 2017). The relationship between financial performance and social responsibility accounting is described as a dialectical relationship, which is a key issue in determining the direction of the relationship (neutral, negative or positive), (Fauzi \& Idris, 2010). The application of social responsibility accounting entails financial costs for the company, and companies hope for economic and social benefits via compensation for those costs.

Based on the above mentioned information, financial performance and social responsibility accounting are the real indicators of the company's performance. Financial performance illustrates the amount of profits and the strength of the company's financial position. Social responsibility reveals the ethical standards in corporate attitudes towards society. We studied the impact social responsibility accounting on financial performance to identify the nature of the impact on the financial performance of the Jordanian shareholding companies listed in the Amman Stock Exchange.

\subsection{Literature Review:}

Kabir \& Thai, 2017, examined the effect of applying corporate social responsibility (CSR) activities on financial performance and type of relationship between CSR and financial performance through corporate governance as a moderating variable measured by (governmental and foreign ownership, size and autonomy of boards of directors in 160 listed firms for the period of 2008-2013. Results showed that SRC activities impact the companies' financial performance positively. Also, corporate governance features such as foreign ownership and size and autonomy of 
Table 1: The research population

\begin{tabular}{|l|l|}
\hline Sector & No. companies \\
\hline Commercial & 15 \\
\hline Education & 6 \\
\hline Healthy & 4 \\
\hline Hotels and Tuites & 12 \\
\hline Media & 2 \\
\hline Technology and communications & 2 \\
\hline Transportation & 14 \\
\hline Energy and utilities & 6 \\
\hline Total & $\mathbf{6 1}$ \\
\hline
\end{tabular}

boards of directors promote the positive relationship between CRS activities and financial performance. By analyzing state ownership, no impact was found regarding the CRS activities and financial performance.

Akisik \& Gal (2017) examined the impacts of customers and employees on financial performance which are third party-reviewed corporate social responsibility reports for emphasizing effective internal controls prepared by internal auditing team of most North American firms through the website of Compustat North America and Global Reporting Initiative data during the period from 2006 to 2012. It was found that the impact of customers and employees on financial performance are influenced by third party-reviewed CSR reports and better internal controls. Moreover, it was found third party-reviewed CSR reports and effective enable the persistence of financial performance efficiency.

Nollet et al, (2016) examined the relationship between Corporate Social Performance (CSP) and Corporate Financial Performance (CFP), using both accounting-based (Return on Assets and Return on Capital) and marketbased (Excess Stock Returns) performance indicators covering the S\&P 500 firms in the period 2007-2011. The results suggest that there is a significant negative relationship between CSP and Return on Capital. However, the study provides evidence of a U-shaped relationship between CSP and the accounting-based measures of CFP, suggesting that in the longer run CSP effects are positive.

Madorran \& Garcia (2016) investigated the type of relationship between CSR and financial performance based on panel data analysis to extract CSR and financial data out of annual reports of a sample comprising firms in the IBEX 35 stock market index, excluding financial sector firms, through the period (2003-2010). The study findings revealed that there is no distinct relationship between CSR activities and financial performance, at least in the case of Spain.

Regarding the causal relationships between the various dimensions of corporate social responsibility (human resources, human rights in the workplace, societal commitment, respect for the environment, market behavior and governance) and financial performance (EPS, return on assets), Rehm and Hirigoyen (2015) chose a sample of 329 listed companies in three geographical areas (the United States, Europe and the Asia-Pacific region) for the years 2009 and 2010. The results show not only that greater social responsibility does not result in better financial performance, but also that financial performance negatively impacts corporate social responsibility.

Usman \& Amran (2015) described the nature and trend of corporate social responsibility (CSR) practices in Nigeria. This is in addition to examine the relationship between the dimensions of CSR disclosures and corporate financial performance (CFP) among Nigerian listed companies. To carry out this research, content analysis was conducted to extract CSR and financial data from annual reports of 68 companies listed on the Nigeria Stock Exchange. The results show that the listed companies used CSR initiatives to communicate social performance to their stakeholders. From the regression analysis, community involvement disclosure, products and customer disclosures and human resource disclosures were found to enhance CFP. The results also reveal a negative relationship between environmental disclosure and CFP, which indicates that disclosure of environmental impact information could be value destroying in Nigeria.

\section{Research Population and Sample}

The research adopted content analysis of annual reports of the research sample which was composed of all service companies listed in the Amman Stock Exchange, totaling (61) companies according Amman Stock Exchange Website in late 2016. Therefore, the research population consisted of all the service companies - about 61 companies - which were mentioned in Table (1) as illustrated:

To select the sample, two conditions should have been fulfilled: first, availability of audited financial statements, which should be published during the research period from 2012 through 2016 . The second condition was that selected companies had not participated in any merger with any other company during the research period. After applying the above-mentioned conditions, a total of 53 companies were selected for the research sample. 


\section{Measurement of research variables:}

\subsection{Social Responsibility Accounting (SRA):}

It was represented in three main areas: (environmental protection, community service, and human resources development.

The three themes of social responsibility were measured by reviewing annual reports of companies regarding their disclosure of their contribution or non-contribution to each of the themes. The value (1) is given if the company discloses its contribution to the theme and the value of $(0)$ for its non-contribution in the theme.

It is worth mentioning that application was reviewed through the disclosure of companies in their annual reports about their contribution or non-contribution in each of the social responsibility themes. The majority of the annual reports of the companies included a separate item about the company's contribution to environmental protection and community service. The human resources item is often separate.

\subsection{Financial performance:}

It was measured based on two main indicators

Earning per Shear (EPS): (after-tax profit - preferred dividend) divided by the average number of common shares. Return on Assets (ROA): measured by dividing net profit after tax on total assets.

\section{Results}

\subsection{Correlation Matrix of Research Variables}

Pearson's correlation matrix was adopted to evaluate the correlation between the independent variables themselves, and then between each independent variable with the dependent variable in each of the research models as follows:

Table 2 Correlation Matrix of Research Variables

\begin{tabular}{|l|l|l|l|l|l|}
\hline Variable & \multicolumn{1}{|c|}{$\begin{array}{c}\text { Environmental } \\
\text { protection }\end{array}$} & $\begin{array}{l}\text { Local } \\
\text { community }\end{array}$ & $\begin{array}{l}\text { Human } \\
\text { resources }\end{array}$ & EPS & ROA \\
\hline $\begin{array}{l}\text { Environmental } \\
\text { protection }\end{array}$ & 1 & & & & \\
\hline ocal community & $\mathbf{0 . 7 2 7 ^ { * * }}$ & 1 & & & \\
\hline $\begin{array}{l}\text { human } \\
\text { resources }\end{array}$ & $\mathbf{0 . 3 7 5 ^ { * * }}$ & $\mathbf{0 . 4 7 9 ^ { * * }}$ & 1 & & \\
\hline EPS & $\mathbf{0 . 0 5 7}$ & $0.131^{*}$ & $0.134^{*}$ & 1 & \\
\hline ROA & $\mathbf{0 . 0 5 1}$ & $0.151^{*}$ & $0.191^{*}$ & $\mathbf{0 . 6 1 0 ^ { * * }}$ & 1 \\
\hline
\end{tabular}

**.Correlation is significant at the 0.01 level (2-tailed).

*.Correlation is significant at the 0.05 level (2-tailed).

Given the statistical data presented in Table (2), it is clear that:

1. There is a strong positive correlation between the independent variables with the highest correlation strength (0.727). It represents the relationship between environmental protection activities and the activities of the local community, while the lowest correlation is between environmental protection activities and human resources development-related activities, equaling (0.375).

2. There is also a statistically significant relationship with varying values of the correlation coefficient between the dependent variable - the financial performance measured by the EPS and each of the independent variables. The strongest coefficient of correlation is the correlation between the EPS and the activities related to human resources development, equaling (0.134). This reveals that there is a weak positive correlation of statistical significance, which means that the financial performance measured by EPS increases with the increasing application of human resources development activities, while the lower correlation coefficient is between financial performance measured by EPS and community service activities, equaling (0.131). This indicates a very weak correlation of statistical significance, which means that financial performance measured by EPS increases with the increasing application of activities related to community service. The table also illustrates the absence of statistically significant relationship between the financial performance measured by EPS and environmental protection activities.

3. There is also a statistically significant relationship with varying values of the correlation coefficient between the dependent variable, the financial performance measured by the return on assets, and each of the independent variables (community service activities and human resources development activities) equaling (0.191). This reveals a weak statistically significant relationship, which means that financial performance measured by return on assets increases with increasing application of human resources development activities, while the lowest correlation coefficient is between financial performance measured by return on assets and activities related to community service, equaling (0.151). Thus, a very weak correlation of statistical significance could be observed. This means that the financial performance measured by return on assets increases with the increasing application 
of activities related to community service. As illustrated in the Table, there is no statistically significant relationship between financial performance measured by return on assets and environmental protection activities. 4. There is a strong positive correlation in the financial performance as the correlation value is $(0.610)$, which represents the relationship between the return on assets and the EPS.

\subsection{Testing Research Hypotheses}

Ho1: Jordanian service companies do not apply Social Responsibility Accounting with relation to (environmental protection activities, community activities and human resource development activities).

In order to prove or negate this hypothesis, a One Sample T-Test was used. Here is a presentation of the results of testing the first main hypothesis. It is based on the value of the arithmetic mean to determine whether there is an application of social responsibility accounting by reviewing the value of the arithmetic mean, which refers to the average application of Social Responsibility Accounting by Jordanian service companies listed in the Amman Stock Exchange, compared with the default mean $(\mu=0.50)$, which was adopted in this paper. In case the arithmetic mean is higher than the default mean this means there is an application of SRA. In order to know if these results are statistically significant, $\mathrm{T}$ value and sig value were adopted. If calculated $t$-value is higher than tabulated $t$-value, this means that there is a statistical significance. For confirmation, the value of sig should be considered.

From the table above, the arithmetic mean in the first main hypothesis is 0.68 , which is greater than the default mean $(\mu \geq 0.5)$.

The results of the test proved statistically significant differences at the mean level (0.05) between the arithmetic mean $(0.68)$ and the default mean $(\mu=0.5)$ where the value of (sig) was less than $5 \%$ and the calculated t-value is (7.759) which is higher than its tabulated t-value (1.653). Therefore, the first hypothesis was rejected and the alternative was accepted. In other words, there is an application of social responsibility accounting by the Jordanian service companies listed in the Amman Stock Exchange, but this level of application is still low.

Ho2: There is no statistically significant impact at $(\boldsymbol{\alpha} \leq \mathbf{0 . 0 5})$ of the social responsibility accounting activities on

Table 3 One Sample T-Test to application of SRA by the Jordanian service companies

\begin{tabular}{|c|c|c|c|c|c|c|}
\hline 오 & Mean & $\begin{array}{l}S- \\
\text { Deviation }\end{array}$ & $\begin{array}{l}T \\
\text { Distribution } \\
\text { Table }\end{array}$ & $T$-Statistics & $d f$ & Sig \\
\hline - & 0.68 & 0.38 & 1.653 & 7.759 & 264 & 0.000 \\
\hline
\end{tabular}

the financial performance measured by the EPS of the service companies listed in the Amman Stock Exchange. In order to determine the result of the hypothesis, the research was based on multiple regression analysis. The value of $(F)$ was used to evaluate the explanatory power of the research model and its suitability to represent the relationship between the independent and dependent variables as in Table (4).

Table 4: multiple linear regression test to $\mathrm{Ho} 2$

\begin{tabular}{|c|c|c|c|c|c|c|}
\hline Variables & $B$ & $\begin{array}{l}\text { Beta } \\
\text { Standardized } \\
\text { Coefficients } \\
\end{array}$ & $T$ & Sig & SigF $=0.000$ & \multirow[t]{2}{*}{$\begin{array}{l}\text { T- Distribution } \\
\text { Table }=1.653\end{array}$} \\
\hline Constant & 0.037 & $\ldots \ldots \ldots$ & 2.869 & 0.039 & $\begin{array}{l}F \quad \text { test } \text { Model }= \\
6.997\end{array}$ & \\
\hline $\begin{array}{l}\text { environmental } \\
\text { protection activities }\end{array}$ & -0.226 & -0.328 & -3.783 & 0.000 & $\begin{array}{l}\text { Adjusted } \quad \mathrm{R}^{2}= \\
0.064\end{array}$ & \multirow{3}{*}{$\begin{array}{l}\text { F- Distribution } \\
\text { Table }=3.417\end{array}$} \\
\hline community activities & 0.231 & 0.320 & 3.490 & 0.001 & $\mathrm{R}^{2}=0.074$ & \\
\hline $\begin{array}{l}\text { human resources } \\
\text { development } \\
\text { activities }\end{array}$ & 0.079 & 0.194 & 2.528 & 0.013 & $\mathrm{R}=0.273$ & \\
\hline
\end{tabular}


Table (4) shows the results of the multiple regression analysis of the independent research variables represented by the CSR activities combined and their impact on the dependent variable (financial performance as measured by EPS). The table shows that the calculated $F$ value is (6.997) and it is significant at (0.05) and larger than its tabular value (3.417), indicating that the proposed model is very suitable for explanatory power but weakly. The results of the regression analysis showed that Sig F is 0.000 lower than the significance level of 0.05 . Therefore, the main null hypothesis of the Second Ho2 should be rejected while the alternative hypothesis should be accepted $\boldsymbol{H a}$. This means that there is a statistically significant impact of social responsibility accounting on financial performance measured by EPS in the service companies listed in the Amman Stock Exchange.

According to the results of the multiple regression analysis, the correlation coefficient $(\mathrm{R})$ value is $(0.273)$ and it confirms a weak positive correlation between the independent research variables represented by CSR activities and the financial performance measured by EPS.

According to the results illustrated in the above table, it is noted that the value of the Adjusted $\mathrm{R}^{2}$ is $(0.064)$. It means that only about $6.4 \%$ of the fluctuations in financial performance measured by EPS which can be explained by changes in independent research variables represented in social responsibility activities - the three activities altogether. Since this value is less than $30 \%$, it is considered to be unreliable, and the significant reduction in the value of the Adjusted $\mathrm{R}^{2}$ factor suggests that other factors outside the interrelationship between these two variables may have a reciprocal effect on each other. Therefore, it is not possible to construct a mathematical equation to predict the value of EPS through the social responsibility accounting activities considered in this research.

Ho3: There is no statistically significant impact at $(\boldsymbol{\alpha} \leq \mathbf{0 . 0 5})$ of the social responsibility accounting on financial performance measured by return on assets in service companies listed in the Amman Stock Exchange.

Table 5: multiple linear regression test to Ho3

\begin{tabular}{|c|c|c|c|c|c|c|}
\hline Variables & $B$ & $\begin{array}{l}\text { Beta } \\
\text { Standardized } \\
\text { Coefficients } \\
\end{array}$ & $T$ & Sig & $\operatorname{SigF}=0.004$ & \multirow[t]{2}{*}{$\begin{array}{l}\text { T- Distribution } \\
\text { Table }=1.653\end{array}$} \\
\hline Constant & -2.467 & $\ldots \ldots \ldots$ & -2.732 & 0.038 & $\begin{array}{l}F \text { test Model= } \\
4.544\end{array}$ & \\
\hline $\begin{array}{l}\text { environmental } \\
\text { protection activities }\end{array}$ & -3.048 & -0.198 & -2.519 & 0.013 & $\begin{array}{l}\text { Adjusted } \quad \mathrm{R}^{2}= \\
0.039\end{array}$ & \multirow{3}{*}{$\begin{array}{l}\text { F- Distribution } \\
\text { Table }=3.417\end{array}$} \\
\hline community activities & 4.122 & 0.192 & 2.308 & 0.022 & $\mathrm{R}^{2}=0.050$ & \\
\hline $\begin{array}{l}\text { human resources } \\
\text { development } \\
\text { activities }\end{array}$ & 4.033 & 0.159 & 2.020 & 0.046 & $\mathrm{R}=0.223$ & \\
\hline
\end{tabular}

Table (5) shows the results of the multiple regression analysis of independent research variables, which are related to CSR activities (environmental protection activities, community service activities and human resources development activities) and their impact on the dependent variable (financial performance measured by return on assets). It can be observed that the calculated $\mathrm{F}$ value is $(4.544)$, which is significant at $(0.05)$ and greater than its tabular value (3.417), indicating that the proposed model was suitable and characterized by its explanatory power but weakly. The analysis of regression results showed that Sig F is 0.004 which is less than the test significance which is 0.05 . Therefore, the third null hypothesis 3 Ho should be rejected and the alternative hypothesis H $\alpha$ should be accepted. There is no statistically significant impact of the social responsibility accounting on financial performance measured by the return on assets in service companies listed in the Amman Stock Exchange.

As shown by the results of the multiple regression test, the correlation coefficient $(R)$ value $(0.23)$ confirms that there is a weak positive relationship between the independent research variables of social responsibility activities (environmental protection activities, community activities and human resources development activities) and financial performance measured by return on assets.

The results showed that the value of the $\mathrm{R}^{2}$ was 0.050 , indicating a low explanatory capacity of $5 \%$ for the return on assets through fluctuations in the three independent research variables.

In view of the results of the above table, the value of Adjusted $\mathrm{R}^{2}(0.039)$ means that only about $3.9 \%$ of the fluctuations in financial performance measured by return on assets can be explained by changes in independent research variables represented by three combined social responsibility activities, namely (environmental 
protection, community service, and human resources). Since this value is less than $30 \%$, it is considered to be unreliable. The significant reduction of the adjusted coefficient of determination indicates that other factors outside the interrelationships between these variables have a reciprocal effect on each other. Therefore, it is not possible to construct a mathematical equation to predict the value of the rate of return on assets through the social responsibility accounting activities considered in this research.

Through re-conducting an analysis of social responsibility activities altogether (activities on environmental protection, community service activities and human resource development activities) and their impact on dependent variables related to financial performance measured by both EPS and ROA. Companies were divided into two groups. The first group consisted of the companies which apply social responsibility under the level of $50 \%$ and their number is 16 companies. The second group consisted of companies that implement social responsibility with a percentage above $50 \%$ totaling 37 companies. Table (6) illustrates the impact of social responsibility accounting on financial performance measured by EPS in service companies listed in the Amman Stock Exchange for groups, as follows:

Table 6: multiple regression test for groups "Impact of SRA on EPS"

\begin{tabular}{|l|l|l|l|l|}
\hline \multirow{2}{*}{ Variables } & \multicolumn{2}{|l|}{ apply more than 50\% } & \multicolumn{2}{l|}{ apply less than 50\% } \\
\cline { 2 - 5 } & $\begin{array}{l}\text { Beta } \\
\text { Standardized } \\
\text { Coefficients }\end{array}$ & Sig & $\begin{array}{l}\text { Beta } \\
\text { Standardized } \\
\text { Coefficients }\end{array}$ & Sig \\
\hline Constant & $\ldots \ldots \ldots$ & 0.026 & $\ldots \ldots$. & 0.582 \\
\hline environmental protection activities & -0.310 & 0.000 & -0.234 & 0.043 \\
\hline community activities & 0.197 & 0.030 & 0.197 & 0.030 \\
\hline human resources development activities & 0.199 & 0.042 & 0.380 & 0.000 \\
\hline F test Model $=$ & 5.476 & & 7.113 & \\
\hline SigF $=$ & 0.001 & 0.000 & \\
\hline Adjusted $\mathrm{R}^{2}=$ & 0.068 & 0.188 & \\
\hline $\mathrm{R}^{2}=$ & 0.083 & & & \\
\hline
\end{tabular}

Table (6) illustrates that there is an impact of social responsibility accounting on financial performance measured in terms of EPS in the service companies listed in the Amman Stock Exchange for each group separately. It also shows the impact of each of the independent variables represented by activities related to social responsibility (environmental protection, community-based activities and human resource development activities) for each group on financial performance measured by EPS in service companies listed in the Amman Stock Exchange. This reveals that companies that implement social responsibility activities at less than $(50 \%)$ have a greater impact and have a greater explanatory power than companies that implement social responsibility activities more than $50 \%$. The Adjusted $\mathrm{R}^{2}$ is 0.188 for companies with less than $50 \%$ which means that only about $18.8 \%$ of the fluctuations in financial performance measured in EPS can be explained by changes in the independent research variables represented by the three social responsibility activities altogether (environmental protection, community service, and human resources). The value of Adjusted $\mathrm{R}^{2}$ was $(0.068)$ for companies that their application rate exceed $(50 \%)$. Since these values are less than $30 \%$, they are considered to be poor and unreliable. Therefore, it is not possible to construct mathematical equations to predict the value of return per equity through the social responsibility accounting activities considered in this research.

Table (7) shows the impact of social responsibility accounting on financial performance measured by the return on assets of service companies listed in the Amman Stock Exchange for groups, as follows: 
Table7 The multiple regression analysis "impact of SRA on ROA"

\begin{tabular}{|l|l|l|l|l|}
\hline \multirow{2}{*}{ Variables } & \multicolumn{2}{|l|}{ apply more than 50\% } & \multicolumn{2}{l|}{ apply less than 50\% } \\
\cline { 2 - 5 } & $\begin{array}{l}\text { Beta } \\
\text { Standardized } \\
\text { Coefficients }\end{array}$ & Sig & $\begin{array}{l}\text { Beta } \\
\text { Standardized } \\
\text { Coefficients }\end{array}$ & Sig \\
\hline Constant & $\ldots \ldots \ldots$ & 0.915 & $\ldots \ldots \ldots$ & 0.112 \\
\hline environmental protection activities & -0.102 & 0.200 & -0.087 & 0.484 \\
\hline community activities & 0.148 & 0.062 & 0.095 & 0.434 \\
\hline human resources development activities & 0.000 & 0.996 & 0.025 & 0.306 \\
\hline F test Model = & 1.329 & & 2.087 & 0.109 \\
\hline SigF= & 0.267 & 0.040 & \\
\hline $\mathrm{Adjusted}^{2}=$ & 0.005 & 0.022 & 0.076 & \\
\hline $\mathrm{R}^{2}=$ & & & \\
\hline
\end{tabular}

From Table (7), it can be observed that there is no impact of the social responsibility accounting on the financial performance measured by the return on assets in the service companies listed in the Amman Stock Exchange for each group separately. Also, it can be noted that there is no impact of the independent variables of the social responsibility activities of each group on the financial performance measured by return on assets in service companies listed in the Amman Stock Exchange.

\section{Conclusion}

After analyzing the data and testing hypotheses, the findings can be summarized as follows:

1. There is an application of social responsibility accounting with respect to (environmental protection activities, community activities and human resources development activities) by Jordanian service companies listed in the Amman Stock Exchange, but this level of application is still low.

2. There is a statistically significant impact at the level $(\boldsymbol{\alpha} \leq \mathbf{0 . 0 5})$ of the social responsibility accounting on financial performance measured by the EPS in the service companies listed in the Amman Stock Exchange. This is because companies' adoption of social responsibility may positively impact the company's image in society. This also adds to improve the safety of its legal and moral position which ultimately leads to maximizing the value of the company's shares and achieving greater profits both in the short-term and long term. It, furthermore, promotes interest in human resources in order to increase their satisfaction and enhance their ability of giving. Therefore, it affects the company's performance positively and thus helps companies' administrations achiever good profits of their shares. These results were similar to those of Kabir \& Thai (2017), Akisik \& Gal (2017) and Nollet et al (2016). However, they contradicted with the study of Madorran \& Garcia (2016) conducted in Spain and the study of Rehm \& Hirigoyen (2015) conducted in the United States, Europe and the Asia-Pacific region.

3 . There is a negative impact between environmental protection activity and financial performance measured by EPS. There is also a statistically significant impact on the local community activity with relation to the EPS, as well as the presence of a statistically significant impact on the activity of human resources development with relation to EPS.

4. There is a statistically significant impact at $(\boldsymbol{\alpha} \leq \mathbf{0 . 0 5})$ of social responsibility accounting on financial performance as measured by the return on assets in the service companies listed in the Amman Stock Exchange. The reason is that the companies; adoption of social responsibility has a positive impact on creating a good image of the company in its society. This is in addition to improving its legal and ethical status which eventually leads to realizing the highest amounts of profits. Such results were similar to those of Kabir \& Thai (2017), Akisik \& Gal (2017) and Nollet et al (2016), while the result contradicted with the study of Madorran \& Garcia (2016) conducted in Spain.

5. There is a statistically significant impact at $(\boldsymbol{\alpha} \leq \mathbf{0 . 0 5})$ of social responsibility accounting with regard to environmental protection activities on financial performance measured by return on assets. This may be due to the fact that the stakeholders in these companies tend to value products or services subject to certain criteria according to specific requirements and specifications with an emphasis on the environmental aspect of these products and services. This finding was in conflict with the study conducted by Usman \& Amran (2015) in Nigeria.

6. There is a statistically significant impact at $(\boldsymbol{\alpha} \leq \mathbf{0 . 0 5})$ of social responsibility accounting in relation to the activities of the local community on the financial performance measured by return on assets. This may be due to the fact that although the activities of the community may have costs endured by the company, but that has a great role in building good relations with the government and the community. This result was similar to that of Usman \& Amran (2015). 
7. There is a statistically significant impact at $(\boldsymbol{\alpha} \leq \mathbf{0 . 0 5})$ of social responsibility accounting in relation to the activities of human resources development on financial performance measured by the return on assets in service companies listed in the Amman Stock Exchange. The reason may be due to the awareness and clear vision among

the administrations of the sample companies which are involved in such investments and the importance of developing and educating staff and employees in social responsibility. This result was similar to that of Usman \& Amran (2015).

\section{Recommendations}

Based on the findings of the research, it is recommended to:

1. Enhance the concept of social responsibility for owners and corporate managers and employees so that the focus is on uniting and promoting their interests socially.

2. Draw investors' attention to the information contained in the annual financial reports on the social responsibility accounting when making their investment decisions, by raising awareness of the need to draw attention to all the items contained in the annual financial and non-financial financial reports.

3. Urge officials in the Amman Stock Exchange and other concerned parties to promote the supervision on the commitment of companies to disclose their social activities and to encourage companies to follow the same approach.

4. Move towards the development of organizations concerned with raising the awareness of corporate boards about the activities of social responsibility accounting to assist corporate boards to identify how to conduct such activities.

5. Utilize accounting disclosure policies applied in foreign countries and apply them in the Amman Stock Exchange.

6. Give more importance by Jordanian companies to the disclosure of social responsibility accounting activities extensively in their financial reports, thus promoting the confidence and respect of society of these corporates.

7. Conduct other studies on the subject of research, namely social responsibility and measuring its impact on the market value of companies.

\section{References}

Akisik, O., and Gal, G., (2017) "The impact of corporate social responsibility and internal controls on stakeholders' view of the firm and financial performance", Sustainability Accounting, Management and Policy Journal, Vol. 8 Issue: 3 , pp.246-280.

Al-Wugayan, A. A. (2017). Does corporate social responsibility matter to financial service representatives in faithexpressive firms?.Journal of Services Marketing, 31(2), 104-118.

Anselmsson, J. and Johansson, U., (2007), Corporate Social Responsibility and the Positioning of grocery brands "An exploratory study of retailer and manufacturer brands at point of purchase, International Journal of Retail \& Distribution Management, 35 (10), 835-856.

Asongu, J.J (2007). "The legitimacy of strategic corporate social responsibility as a marketing tool "journal of business and public policy, 1, (1), pp. 2-4.

Balabanis, P, (1998), Social Responsibility, American Business Review, 1, (9), pp. 68- 81.

Bhunia A., Mukhuti S., \& Roy S. (2011) Financial Performance Analysis-A Case Study, Current Research Journal of Social Sciences, Vol. 3, No. 3, p 269-275.

Bremner, C. (2009). Sustainable tourism moves slowly in the right direction. Retrieved from Euro monitor International. Jhu Press.

Chtourou, H., Chtourou, H., Triki, M., \&Triki, M. (2017). Commitment in corporate social responsibility and financial performance: a study in the Tunisian context. Social Responsibility Journal, 13(2), 370-389.

DiSegni, D. M., Huly, M., \& Akron, S. (2015). Corporate social responsibility, environmental leadership and financial performance. Social Responsibility Journal, 11(1), pp. 131-148.

Eweje, G. and Bentley, T. (2006). CSR and staff retention in New Zealand companies: A literature review. Department of Management and International Business Research, Working Paper series, (6) Auckland, NZ: Massey University.

Famiyeh, S, (2017). Corporate social responsibility and firm's performance: empirical evidence. Social Responsibility Journal, 13(2), 390-406.

Fauzi, H and Idris, K. M. (2010) the relationship of CSR and financial performance: new evidence from Indonesian companies, Social and Environmental Accounting, Vol. 3, No. 1, Available at SSRN: https://ssrn.com/abstract=1694284.

Ferell, O., \&Fraedrich, J. (2012) Business Ethics: Ethical Decision Making \& Cases, Cengage, $9^{\text {th }}$ Edition, U.S.A. Field, A. (2013), Discovering Statistics Using SPSS, 8th Ed Sage.

Gholami, S., Parvizi, M., TamriNeia, A., Nemati, S., Abgineh, M., \&Emami, M. (2012). Social Responsibility Accounting: From Theory to Practice. Journal of Basic and Applied Scientific Research, 2(10), 10111-10117. 
Gibson.C.H (2013) Financial Reporting and Analysis: Using Financial Accounting Information. 13 ${ }^{\text {th }}$ (ed.): South - western: Cengage Learning.

Gitman, L. J., Juchau, R., \& Flanagan, J. (2015). Principles of managerial finance. Pearson Higher Education AU. Hayduk, L. A. (1987). Structural equation modeling with LISREL: Essentials and advances. Jhu Press.

Hirigoyen, G., \&Poulain-Rehm, T. (2015). Relationships between Corporate Social Responsibility and financial performance: What is the Causality? Journal of Business \& Management, 4 (1), pp.18-43.

Kabir, R \& Thai, H. M. (2017). Does corporate governance shape the relationship between corporate social responsibility and financial performance? Pacific Accounting Review, 29(2), pp. 227-258.

Linthicum, C. Reitenga, A L and Sanchez, J M. (2010). Social responsibility and corporate reputation: The case of the Arthur Andersen Enron audit failure. Journal of Accounting and Public Policy.29 (2010) 160-176.

Madorran, C., \& Garcia, T. (2016). Corporate social responsibility and financial performance: the Spanish case. Revista de Administração de Empresas, 56(1), 20-28.

Magnanelli, B. S., \&Izzo, M. F. (2017). Corporate social performance and cost of debt: the relationship. Social Responsibility Journal, 13(2), 250-265.

Mahoney, L., Roberts, R. (2007) Corporate Social Performance, Financial Performance and Institutional Ownership in Canadian Firms, Accounting Forum. Elserier, Vol. 31, Issue 3, Pp. 233-253.

Myers, D. (1990). Surfaces, interfaces and colloids. New York etc.: Wiley-Vch.

Nollet, J., Filis, G., \&Mitrokostas, E. (2016). Corporate social responsibility and financial performance: A nonlinear and disaggregated approach. Economic Modeling, 52, pp. 400-407.

Orlitzky M, Schmidt F, Rynes S, (2003) Corporate Social and Financial Performance A Meta-Analysis Organization Studies, 24, 3, 403-441.

Pawa, A. and Krause, R. (1996). Corporate Social Responsibility, Strategic Management Journal, 8, (2), pp. 1932.

Rahahleh, m, y and sharairi, j a. (2008). The extent of social responsibility accounting application in the qualified industrial zones in Jordan. International management review. 4.2.5-17.

Swamynathan, M. (2017) Mastering Machine Learning with Python in Six Steps, Apress, Berkeley, CA.

Turcsanyi, J., \&Sisaye, S. (2013). Corporate social responsibility and its link to financial performance: Application to Johnson \& Johnson, a pharmaceutical company. World Journal of Science, Technology and Sustainable Development, 10(1), 4-18.

Usman, A. B., \&Amran, N. A. B. (2015) "Corporate social responsibility practice and corporate financial performance: evidence from Nigeria companies", Social Responsibility Journal, Vol. 11 Issue: 4, pp.749-763.

Wang, S., Huang, W., Gao, Y., Ansett, S., \&Xu, S. (2015). Can socially responsible leaders drive Chinese firm performance? Leadership \& Organization Development Journal, 36(4), 435-450.

Wang, Y, and Fan, W, (2014), "R\&D reporting methods and firm value: evidence from China", Chinese Management Studies, Vol. 8 No. 3, p 